\title{
Is it an institution, digital or social inclusion that matters for inclusive growth? A panel data analysis
}

\author{
Aribah Aslam $^{1} \cdot$ Amjad Naveed $^{2}$ (D) . Ghulam Shabbir ${ }^{3}$ \\ Published online: 27 June 2020 \\ (c) Springer Nature B.V. 2020
}

\begin{abstract}
This study empirically examines the impact of institutional quality, social inclusion and digital inclusion on inclusive growth across different economies characterized by different income groups. Particularly, the study examines the impact of institutions on inclusive growth by using the panel data for 83 countries over the period 2010-2017. For empirical specification, we used two-steps system-GMM estimation technique to tackle endogeneity and min-max normalized indexing technique to construct the indices for inclusive growth, social inclusion, digital inclusion and institutional quality. The results of this study show that there is a direct link between institutional quality and inclusive growth for a higherincome group of countries but not in the rest of the income groups. Contribution of social and digital inclusivity is significant in all three income groups, except for social inclusion in middle-income countries. From the policy point of view, these findings suggest that establishing and strengthening the institutional structure in low- and middle-income countries can contribute towards better and higher inclusive growth.
\end{abstract}

Keywords Social inclusion · Digital inclusion · Inclusive growth · Institutions · Panel data · System GMM

JEL Classification $\mathrm{E} 02 \cdot \mathrm{F} 01 \cdot \mathrm{F} 41 \cdot \mathrm{F} 43 \cdot \mathrm{O} 10 \cdot \mathrm{O} 11 \cdot \mathrm{O} 17 \cdot \mathrm{O} 43$

\section{Introduction}

The relationship between institutions, income inequalities and economic growth has long been a part of debate related to public policy. However, hardly any comprehensive study has analyzed the impacts of institutions, socio-digital connectivity on inclusive growth. The catastrophe of Washington Consensus in the early 1990s, the emergence of new institutional economics and growing pressure of International Organizations (including few

Amjad Naveed

amjadnaveed9@yahoo.com; amjadn@btech.au.dk

1 Department of Economics, Nur International University, Lahore, Pakistan

2 Department of Business Development and Technology (BTECH), Aarhus University, Herning 7400, Denmark

3 Department of Economics, Forman Christian College (A Chartered University), Lahore, Pakistan 
United Nation's agencies), Non-governmental organizations, governments of developing world, and activists forced the International Financial Institutions (World Bank and International Monetary Fund) to address the twin evils of inequality and poverty reduction through pro-poor growth (Saad Filho 2010). This transferal in the global economic debate on inclusive growth is also manifested by international commitments to the Sustainable Development Goals. ${ }^{1}$ In the early 2000s, the pro-poor policy framework was constructed focusing on the basic needs of the poor and improvement in the distribution of resources, and fruits of economic growth in poor countries. With the collapse of pro-poor growth debate, World Bank and its associates pave the way for the dawn of inclusive growth paradigm in the late 2000 s.

Inclusive growth and pro-poor growth are in line in terms of absolute definition but not in relative terms. In absolute terms, growth is regarded to be pro-poor as it benefits the poor in absolute terms, as shown by some poverty measures (Ravallion and Chen 2003). However, in relative terms, it will be pro-poor if and only if, the incomes of poor people grow faster than the overall population of a country i.e. reduction in inequality (Dollar and Kraay 2002; IMF 2011). Thus, inclusive growth is an improved form of pro-poor growth that focused on the improvement of productivity and the creation of new productive employment opportunities to efficiently curtail poverty and inequality. This implies that the focus of inclusive growth is productive employment creation rather than mere income distribution (Bourguignon and Morrisson (1989); World Bank 2008). Hence, inclusive growth has emerged as a paradigm shifter, yet scarcely analyzed in the literature (Perch 2011; UN/DESA 2012). Inclusive growth embraces not only the income dimensions but also the non-income dimensions of human well-being i.e. change in social and economic conditions (Aslam et al. 2017).

Besides, inclusive growth guaranteed social welfare, as the labor force actively contributes to the growth process. Several countries from the developing world such as China, India, and Latin America have tried to reduce poverty, but, unfortunately, income inequalities grown-up in these regions. The core agenda of inclusive growth is creating an environment of equitable employment opportunities without undermining the poor segments of society. In the present era, inclusive growth has emerged as a major tool that not only curtails poverty but also improves and uplifts the lives of people. Because it doesn't only focus on the distribution of the fruits obtained from the growth of any one sector of the economy but also focused on the creation of enabling environment that is required for productive employment opportunities (ADB 2012; Abosede and Onakoya 2013). It enables people to become a part of the productive process and contribute towards the inclusion of deprived segments of the society (Sachs et al., 1995). It helps to reduce inequality and poverty by reducing unemployment rates and provide equitable opportunities for productive employment. A recent challenge faced by policymakers is to enhance social integration with digital inclusion to promote inclusive growth. Such a link is still in the early stages of development with very little focus on it, especially, in the presence of different institutional structures (Wang and Naveed 2019; Djankov et al. 2003). Moreover, these factors alone cannot catalyze inclusive growth until poverty and inequality are addressed. Keeping in view these problems, this study investigated the role of socio-digital inclusion and institutional quality in achieving inclusive growth.

\footnotetext{
1 "SDG Goal \# 8: Promote sustained, inclusive and sustainable economic growth, full and productive employment and decent work for all.
} 
Theoretical and empirical literature investigated economic and non-economic dimensions that significantly contribute to the achievement of inclusive growth. Some studies examined economic dimensions such as sustainable and equitable growth (Ali and Son 2007a, b; Lin 2004) and documented that the continuous flow of technology IT, Computers, Digital inclusion) and industrial innovation is the key to sustained economic growth (Flynn et al. 2005). Besides, the role of quality of infrastructure and agriculture is examined by Ali and Yao (2004), Fernando (2008) and Bolt (2004). Asian Development Bank studies cited the social dimensions that are essential to achieve inclusive growth. Ali and Son (2007a, b) investigated the role of security, Tandon and Zhuang (2007) highlighted the health in the achievement of inclusive growth. Meschi and Vivarelli (2007) investigated the relationship between trade flows and inequality. Ali and Son (2007a, b) analyzed the impact of institutions via social inclusion and empowerment, as Social inclusion implies the removal of all institutional and policy restrictions that impede economic growth (Dias 2014). Empowerment indicates access to productive assets, capacities and resources which help all individuals to actively participate in the process of growth. Fernando (2008) considered the political dimension (participation in the political processes), required to achieve inclusive growth. Aslam and Zulfiqar (2016) have probed into the role of financial inclusion concerning inclusive growth but have ignored the imperative role of socio-digital inclusion in inclusive growth. Ali (2007) recognized the public-private partnership is the need for inclusive growth. Aribah (2016) concluded that many developing countries have reduced poverty but exercising the rising trend in income inequality. Hence, a rising trend in inequality keeps these nations away to achieve multiple welfare goals (Zulfiqar et al. 2017).

Numerous studies have investigated the various dimensions of inclusive growth and portrayed mixed findings. The debate on the means and determinants of inclusive growth has not been settled yet. Countries may have achieved respectable short-run economic and political gains but still lacks in sustainable inclusive growth. Moreover, the existing literature on the subject lacks in theoretical and empirical investigations and need to explore the influences of institutions and socio-digital inclusions on inclusive growth simultaneously, and also how this linkage may suffer from endogeneity issue. It can be reasoned that a theoretical foundation is crucial to develop the mechanism through which institutions are linked with inclusive growth while keeping digital and social inclusion into consideration. Moreover, tackling the endogeneity problem is imperative for consistent and robust empirical results. Nawaz (2014) has examined the effect of institutions on economic growth by using the SYS-GMM estimation technique, which caters to the issue of endogeneity (Qian 2014). Nevertheless, the study has pooled different natures of countries into one sample, which fails to cater to the issue of heterogeneity. Besides, it cannot be rationalized to test a group of heterogeneous countries. Additionally, the focus of the study is economic growth not inclusive growth, which is more desirable for policymakers. Therefore, the present study aims to fill the existing gap in literature after taking care of the above-mentioned shortcomings in the literature.

Income inequalities are surging in the world on average, despite its exhilarated GDP growth rates and substantial reduction in poverty rates over the years. Literature shows that high economic growth rates had remained in thoughtfulness to effectuate economic development but the notion of "inclusive growth" was completely missed out in the process of economic growth. Thus, to overcome this gap in the literature, the motivation to do this study is to methodically investigate the determinants of inclusive growth, along with associations among different income groups; particularly, focus on the role of institutions, digital inclusion and social inclusion in embracing inclusive growth. The study, along these lines, suggests how inclusive growth may be achieved in three income groups. Hence, the 
study aims to: (1) construct the indexes to capture different dimensions of digital inclusion, social inclusion, institutional quality and inclusive growth. (2) To estimate the impact of digital inclusion, social inclusion, institutions on inclusive growth after controlling the effects of relevant variables in three income countries group: High-income countries (HYCs), middle-income countries (MYCs) and low-income countries (LYCs). (3) To suggest pathway/policy for LYCs and MYCs to achieve the inclusive growth equivalent to HYCs.

The study tried to answer the research questions: Does socio-digital inclusion helps to achieve inclusive growth in the groups of three income countries? If yes, how countries with low inclusive growth can catch up with the high inclusive growth achieved by the high-income countries? The study tested the hypotheses of inclusion differences, posits that high, middle- and low-income countries differ in their social inclusion, digital inclusion and inclusive growth, after taking care of their institutional structure. The second hypothesis is concerned with the comparisons between the achievement of inclusive growth in different income groups. The validity of this implies that the achievement in inclusive growth varies among different income groups, and they can achieve higher inclusive growth by designing focused policies on the determinants of inclusive growth. Consequently, a group of countries with higher inclusive growth, are those that have been successful in bolstering the digital and social inclusion, while accomplishing a strong institutional structure. The third Hypothesis of Jeopardy holds that low-income countries are more vulnerable to the harms of low inclusive growth. They require a pathway to achieve inclusive growth by learning from countries better than them in terms of higher inclusive growth.

This study contributes to the existing literature as: first, the study constructed three different types of inclusion indices; digital inclusion index, social inclusion index, inclusive growth index, and institutional quality index. The purpose of these indices is to capture the different dimensions of inclusion and then ranked the countries based on these indices. Second, this study quantifies the impact of these indices at different stages of income groups. Third, it addresses the problems of endogeneity and heterogeneity using the twostep SYS-GMM estimation technique.

The remainder of this study is organized as follows: Section two provides conceptual linkages between social inclusion, digital inclusion, institutional quality and inclusive growth. Section three offers a detailed literature review of selected studies. The methodology and data are explained in Section four. Section five presents empirical results and discussion. Finally, Section six concludes the study and suggests policy implications and section seven shares the scope for future research.

\section{Inclusive growth: conceptual linkages}

Following Silver (1994) and DESA (2009), conceptual linkages between social inclusion, digital inclusion and inclusive growth are developed. This relationship is portrayed using a radial circle as shown in Fig. 1. Today's growing digital technology has spurred social inclusion and significantly influenced people's choices and decisions, which are shaped by the embedded institutional structure of the country. In this respect, digital inclusion could also play a central role in achieving such goals. Digital inclusion makes individuals more productive by choosing their desired jobs at competitive wages, without affecting the freedoms of people (Corbi 2007). However, social and digital inclusion remained much influenced by institutions i.e. informal norms, enforcement mechanisms and formal rules 


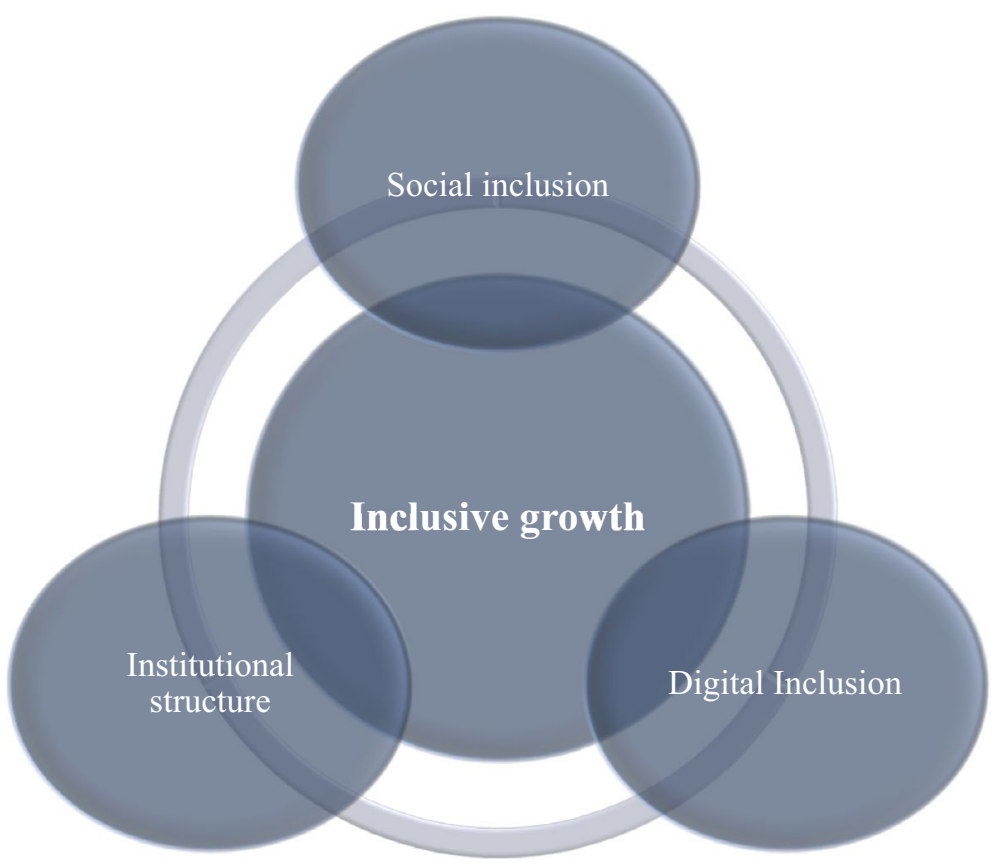

Fig. 1 Conceptual linkages based on radial circle. Source: Developed by the Authors

of every set of countries (Faundez 2016; North 1994; North and Davis 1970; Przeworski 2004; Aslam et al. 2017; Richardson and Bogart 2009). Socio-cultural traits and social behavior jointly might compel people towards inclusive growth. Acemoglu and Robinson (2012) elaborated on the role of extractive and inclusive political institutions that leads to power, prosperity and reduction in poverty, which one is a major constituent of inclusive growth. Since studies by World Bank (2002), North (1994), Shirley (2005, 2008) advocates that institutional role became prominent and emerged as an important factor to promote and sustain economic welfare. It is important to note here that the need for inclusive growth is not only realized due to the lack of economic and social opportunities for the poor, but it may also arise as an outcome of poor income distribution, weak institutional structure, unheard voices of underprivileged, illiteracy, dictatorial categorized power concentration in developing world.

Figures 2 and 3, provides an accumulative picture of inclusive growth index (IGI) for world level data based on recent 6 years. The value of the inclusive growth index is greater than 50 for countries falling in the high-income group. Norway is ranked as 1 st, followed by Iceland, Luxembourg, and so on (as shown in Fig. 2).

Interestingly, China (with score 58.52) is ranked higher in terms of inclusive growth than Japan (score: 56.10). Sri Lanka is having score 48.13 has a higher literacy rate than India, which is growing more inclusively than it, as its IGI score value is 50.24 . It may be due to the dominance of some variables such as employment to population ratio, income inequalities or per capita income growth in the sample for one country and which may not be high for another country. It is interesting to note that the IGI score of Pakistan (53.52), which has lower economic growth rates than Sri Lanka and India but performed better in terms of inclusive growth than these nations. The results of Pakistan are consistent with 


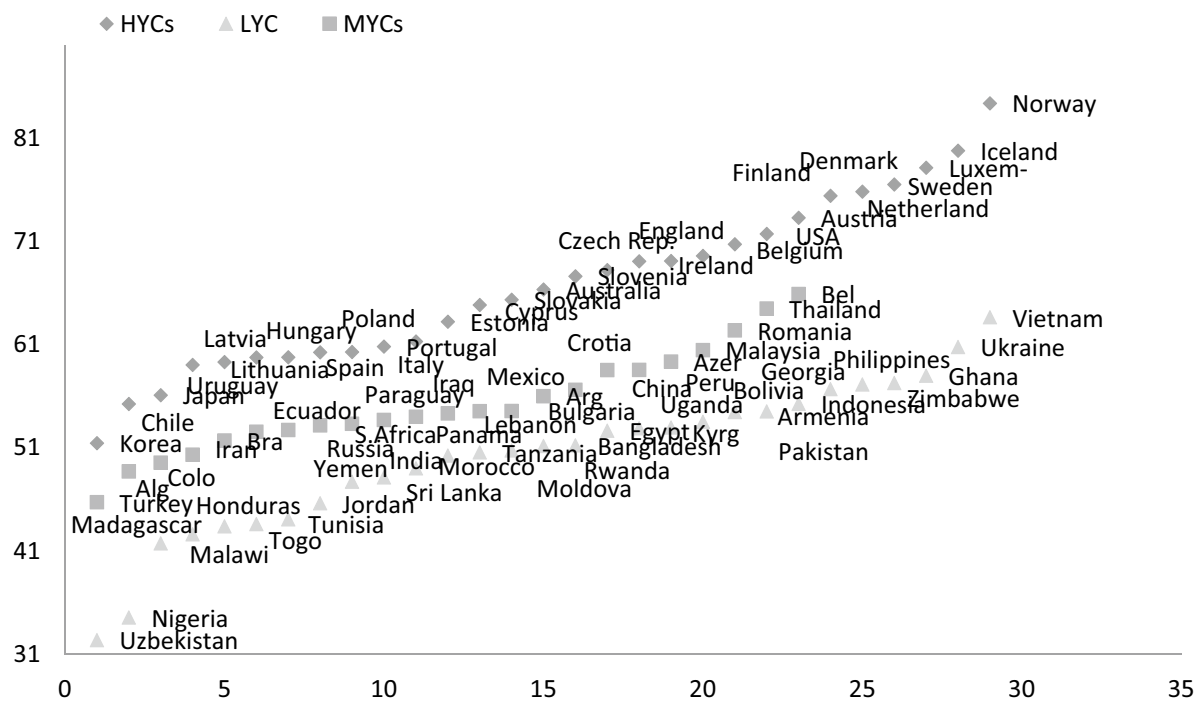

Fig. 2 Countries ranking based on inclusive growth index. Source: Developed by the Authors based on Table 3 in the Appendix

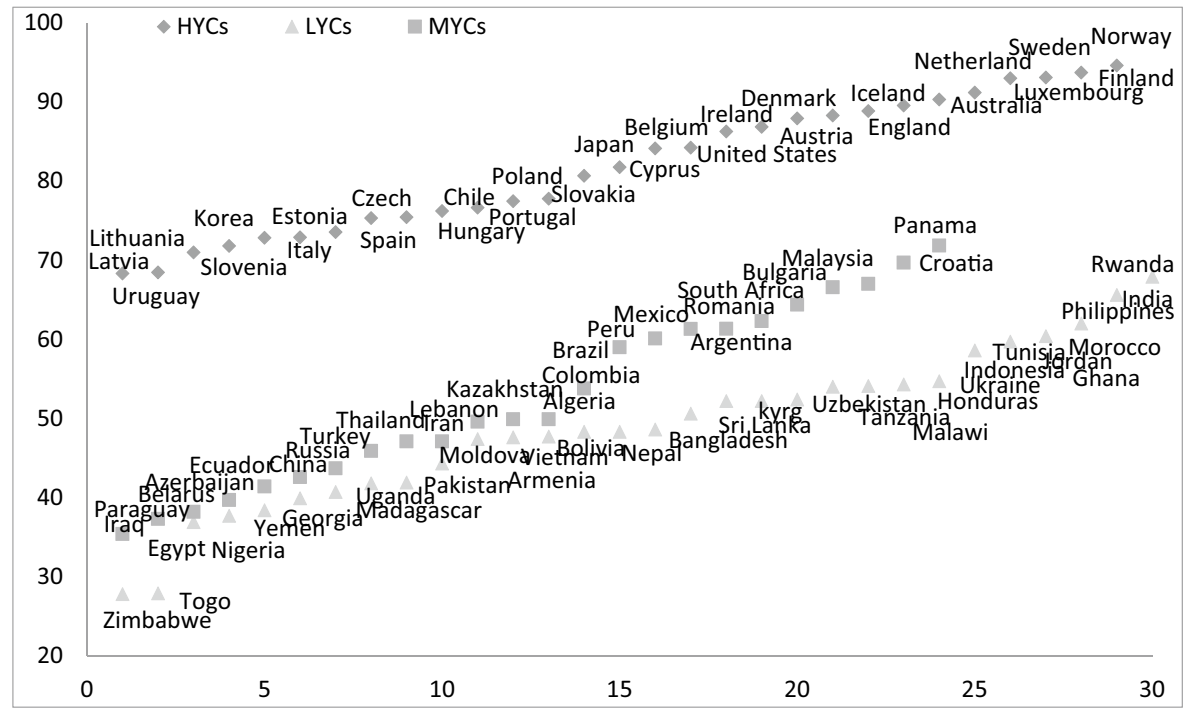

Fig. 3 Countries ranking based on Institutional Quality Index. Source: Developed by the Authors based on Table 3 in the Appendix

Saima and Javed (2011). The performance of Uzbekistan and Nigeria is the worst in terms of inclusive growth. The gap between middle income and low-income groups is small (5 to 6 average points) that implies middle-income countries might be growing rapidly as 
Fig. 4 Comparison based on IGI. Source: Developed by the Authors

Fig. 5 Comparison based on IQI. Source: Developed by the Authors

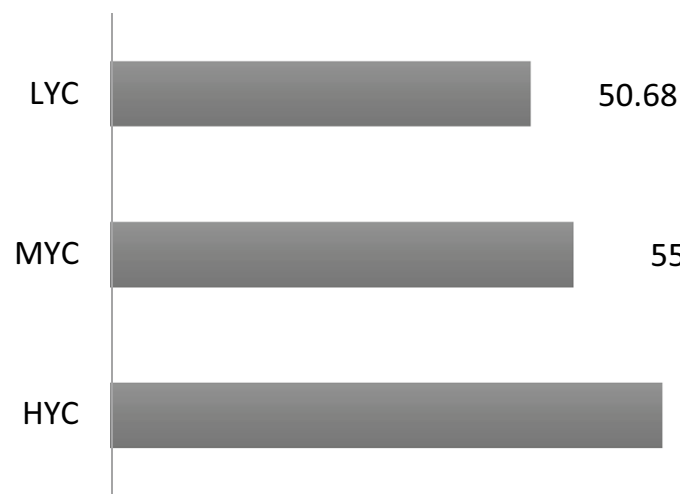

55.89

66.62

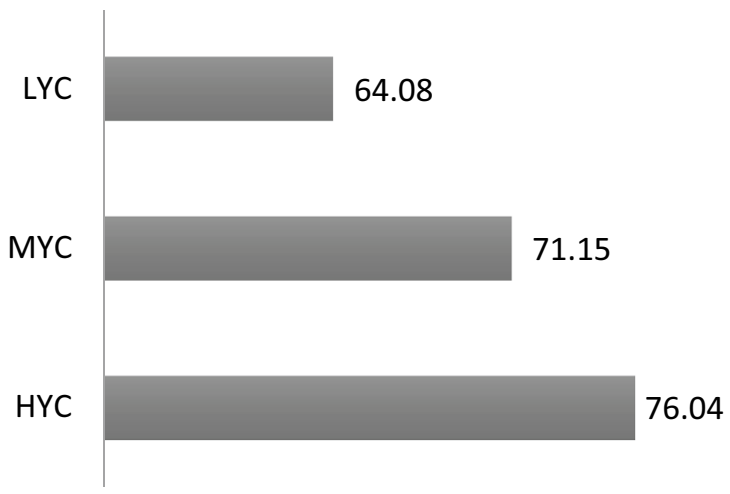

compared to low-income nations, but in terms of inclusive growth does not significantly differ from low-income countries.

Countries ranking based on institutional quality index indicates that high-income countries are ranked at the top, as shown in Fig. 3. Finland ranked at the top with scores 94.62 which shows the best institutional structure in the world, followed by Norway (93.74), Sweden (93.12). The largest economy in the world (USA) ranked in the 13th position with a score value of 84.24. According to this ranking, Zimbabwe has the poorest institutional structure with a score of 27.77 .

Figures 4 and 5 portrays an accumulative picture based on the inclusive growth index (IGI) and institutional quality index (IQI). ${ }^{2}$ These figures indicate the imperative economic rationale of why high-income countries have a higher level of inclusive growth. This implies that as income level increases, institutional quality improves, which helps in achieving inclusive growth, as predicted by North (1994) World Bank (2002) and North and Davis (1970).

The above-cited evidence leads to conclude that institutional quality and inclusive growth go hand in hand and hence the role of institutional quality and inclusive growth cannot be explored in isolation. In the pursuit of the above conceptual relationships, the

${ }^{2}$ Average values for years 2010-2016 are reported in Figs. 2, 3, 4, 5. 
study aims to point out major determinants of inclusive growth, for three distinct income groups' i.e. low-income countries (LYCs), middle-income countries (MYCs) and highincome countries (HYCs). In addition to the above, the present study explores the associations between these income countries groups of countries as per their achievement in inclusive growth by improving institutional quality, spreading digital technology and social inclusion.

\section{Literature review}

Pro-poor growth and strong institutional structure is a necessary condition for inclusive growth (Aribah et al. 2016). A review of quantitative cross-country studies indicates that all governance indicators (measures of political stability and rule of law) are correlated with higher growth, but portrays mixed results about poverty reduction. However, governance indicators related to transparency (measures of civil liberties and political freedom) have reduced poverty in the short term but provides mixed evidence about the relationship between these indicators and growth. Lopez (2004) evaluated pro-growth policies, whether also pro-poor. He reported that policies are effective in reducing poverty in long but not in the short run. Kraay (2004) found that improvement in the rule of law and accountability positively impacts on the growth. Habito (2009) reported a significant impact of governance, public expenditures in social services, the sectoral composition of output growth, and contribution of agriculture to GDP growth on inclusive growth. Kaufmann et al. (2002) also indicated a strong positive correlation between per capita income and governance across countries. Dollar and Kraay (2002) found that effective rule of law will increase the share of the poorest $20 \%$ of the population in growth dividends, and similar findings are reported by Kraay (2004).

The other important factor that makes inclusive growth more desirable than pro-poor growth is the need for shortening the gap among income differences. In a seminal study, Kuznets (1955) reported an inverted-U relationship between economic development and inequality. At the initial stage of development, inequality increases but it starts decreasing as a larger segment of the population find job opportunities in the high-income sector. However, empirical findings of Deininger and Squire (1996) do not support the existence of an inverted-U relationship between per capita income and inequality. Goudie and Ladd (1999) found that growth systematically impacts income inequality. Forbes (2000) reported an inverse linkage, that higher inequality promotes growth in the short and medium-term. Alesina and Rodrik (1994) analyzed the political aspect and found that the increase in inequality compels the poor to have less voice and accountability. Berg and Ostry (2011) found that lesser inequality prevailed during the spells of sustained growth. Few studies investigated the effect of inequality on poverty. Deininger and Squire (1998) found that about $20 \%$ of the poorest class of the society mostly suffer from the growth reducing the effects of inequality. Ravallion (2001) also supported these findings and reported that poor class might get a larger share of gain resulting from redistribution of income, but also hurts more than the richer portion of the population from economic shrinkage. Meschi and Vivarelli (2007) investigated the relationship between trade flows and inequality. Their findings suggest a weak relationship between these variables for developing countries. Besides, it supported that trading nations' technological differentials have played an imperative role in shaping the distributive effects of trade openness. 
Economic Inequalities and inclusive growth discussion widely emerged after the financial crisis in 2008 and the Arab Spring in 2011 in global debates. According to Ali and Son (2007a, b), "Inclusive growth ensures fair and equal access to all stratum of society, including disadvantaged and marginalized, to opportunities created". Various studies have identified different socio-economic factors required to achieve inclusive growth. Anand et al. (2013) investigated the role of macroeconomic stability, human capital, and structural improvement in achieving inclusive growth in emerging markets over 3 decades. The study found that all these factors positively contributed to achieving inclusive growth in the sample countries. Tripathi (2013) found the lower inclusive growth and poverty in 54 populated cities of India along with the increase in inequality from 2004-05 to 2009-10. Ianchovichina and Lundstrom (2009) found that the main hurdles in achieving inclusive growth in Zambia are poor education and health, access to capital and credit, infrastructure and government failure. Few studies found a rising trend in inequality with technological changes, financial deepening, and certain aspects of globalization (Acemoglu et al. 2001; Acemoglu et al. 2008; Aizeman et al. 2012; IMF 2011).

Another dimension of inclusive growth in the empirical literature is also institutional, which was referred by Ali and Son (2007a, b) as social inclusion. Social inclusion implies the removal of all institutional and policy fences that constrain the performance of the economy (inclusive growth). Ali and Zhuang (2007) explored that social inclusion needs interventions in education, health, and other social services (water and sanitation) to promote human capacities. Tandon and Zhuang (2007) concluded that the top priority of the government must be the removal of health-related inequalities. Research studies on social capital in the context of OECD during the decades 1980s/1990s found a beneficial impact of social interconnection and trust performance of the economy (Hausmann et al. 2014). Narayan (1997) found a direct and causal effect of social capital on poverty in Tanzania. Easterly et al. (2006) found the impact of social cohesion on growth through institutional quality.

There is also a need to modernize social inclusion, which can be done through digital inclusion. In the global everyday life, the use of digital technologies is considered as a major tool to bridge distances among people relating to social exclusions (Wallcook and Morris 2017). On the other hand, a strand of literature does not consider digital human capital as the only key to ensure economic growth/inclusive growth. Rather, they believe that inequality in incomes and social groups requires a more nuanced plan to address the problems of today (Bach et al. 2013). There has been ample literature supporting the need for social inclusion and also digital inclusion to look at the economies of the world. However, no significant study has addressed inclusive growth through the lens of social and digital inclusion. Along with that, a large amount of literature while considering the role of socio-digital inclusion in economic growth has missed out the role of institutions (Mutsvairo and Ragnedda 2019; Ragnedda 2019; Jin 2017; Pitakdumrongkit 2018).

Inclusive growth has been lackluster for more than decades and it is in dire need, particularly after the post-COVID-19 pandemic. The economic growth process has not only been slowed down but also halted because of coronavirus. It has resulted in more severe impacts on poverty, unemployment, social exclusion and income inequalities. The recovery from the post-covid-19 scenario would be a journey of unwanted shocks to the economy which would be uneven, slow and more demanding of digital inclusion (Parrott et al. 2020). The global financial crises of 2007-08, which were much less severe than what the future, appeared to pick up in a synchronized way for more 
than 10 years (Kim and Qureshi 2020). It might take many more years for the world to recover and achieve inclusive growth in the post-covid-19 period. This whole episode has also built up the urgent need for technology and digital inclusion (Klonowska and Bindt 2020). Considering this, the above-cited literature has discussed the role of the institution in inclusive growth but still, there is a gap in the literature, which defines the social and digital inclusion, and further analysis of their impacts on inclusive growth for different economies. The study in hand will fulfill this gap by using a comprehensive theoretical and quantitative approach as discussed in the next section.

\section{Theoretical background and model specification}

Theoretical debate on the relationship between economic growth, poverty and inequality emerged since Kuznet's (1955) and Solow's (1956). After the failure of the Washington Consensus, and the advent of institutional economies compelled the world financial institutions to opt pro-poor growth strategy to reduce inequality and poverty, which was later emerged into inclusive economic growth. Numerous studies extended the endogenous growth model and introduced models to investigate multidimensional aspects of inclusive growth (Bhalla and Das 2007; McKinley 2010; Rauniyar and Kanbur 2010; de Haan and Throat 2013; Anand et al. 2013; Aslam 2020).

The neoclassical growth model presented by Solow (1956), indicates that the output of the economy depends upon labor (L) and capital (K). The aggregated functional form can be shown as below:

$$
Y_{t}=f\left(K_{t}\right)\left(L \cdot T_{t}\right)
$$

where ( $\mathrm{L}^{*} \mathrm{~T}$ ) is effective labor, T shows labor augmented technology, $\mathrm{Y}$ is output and $\mathrm{K}$ is capital. Solow (1956) assumes that all factors of production are fully employed, ${ }^{3}$ and as labor (L) grows, technology $(\mathrm{T})$ will expand at that rate ( $\mathrm{n}$ and $\mathrm{g}$ are growth rate of $\mathrm{L}$ and $\mathrm{T}$, respectively). Thus, it implies that output (Y) does not increase as a result of expansion in labor and capital (K) only, but also technology plays a significant role in output expansion when it is combined with labor i.e. (L.T). Dividing Eq. (1) by T.L (effective labor), we get the following Eq. (2).

$$
\mathrm{Y}_{\mathrm{t}}^{*}=\mathrm{T} \cdot \mathrm{f}\left(\mathrm{K}_{\mathrm{t}}^{*}\right)
$$

whereas $\mathrm{Y}^{*}(=\mathrm{Y} / \mathrm{T} . \mathrm{L})$ is output per effective labor and $\mathrm{K}^{*}(=\mathrm{K} / \mathrm{T} . \mathrm{L})$ shows capital per effective labor. Solow (1956) also assumes that capital depreciates (d) at time (t) grows. The relationship between output per effective labor, initial rate of output growth (y), savings/investment rate (s), depreciation rate (d), population growth rate (n) and technology or knowledge (T) may write as below.

$$
\mathrm{Y}^{* *}=\mathrm{g}(\mathrm{y}, \mathrm{s}, \mathrm{d}, \mathrm{n} ; T)
$$

Thus, output per effective labor grows as a function of initial output growth, savings, depreciation, Technology growing as the population growth rate (n). This implies that as labor grows, technology also expands at a population growth rate and as a result,

\footnotetext{
${ }^{3}$ It is yet to be noted that the model assumes that $\mathrm{L}$ and $\mathrm{K}$ is fully employed in country. However, the case is weak for LDCs, which will be tested through empirical modeling.
} 
output $\left(\mathrm{Y}^{* *}\right)$ grows, keeping saving/investment rate and depreciation constant. Literature has pointed out that with an expansion of economic freedom $(\mathrm{F})$, the effectiveness of labor (L) grows and results in technology $(\mathrm{T})$ growth and thereby output growth $\left(\mathrm{Y}^{* *}\right)$. This can be mathematically represented as:

$$
\mathrm{Y}_{\mathrm{t}}^{* *}=\mathrm{g}\left(\mathrm{y}, \mathrm{s}, \mathrm{d}, \mathrm{n} ; \mathrm{F}_{\mathrm{t}}\right)
$$

This growth in output per effective labor will lead to a reduction in poverty and increase employment opportunities for people, thus this will lead to inclusive growth (IG). Since growth is the first condition to inclusive growth, and in hand, the study goes one step ahead to economic growth and investigates the factors that significantly contribute to the nation's inclusive growth (IG). The functional relationship is shown as follows:

$$
\mathrm{IG}_{\mathrm{t}}=\mathrm{g}(\mathrm{y}, \mathrm{s}, \mathrm{d}, \mathrm{n})
$$

We make a hypothesis that as population (n) grows, so does the freedoms (F) expands that people enjoy. Freedoms are a necessary component of social inclusion. As a result, society becomes more socially inclusive (SI) and resultantly output ( $\left.\mathrm{Y}^{* *}\right)$ grows. As effective output per labor expands, poverty reduces accompanied by employment increases, which leads to inclusive growth (IG). This can be mathematically written as follows ${ }^{4}$ :

$$
\mathrm{IG}_{\mathrm{t}}=\mathrm{g}\left(\mathrm{y}, \mathrm{s}, \mathrm{d}, \mathrm{n}, \mathrm{SI}_{\mathrm{t}}\right)
$$

Equation (6) shows the impact of social inclusion (SI) on IG, holding other factors as constant. Studies show that as the population grows at $n$, society not only become socially inclusive through media and IT, but technology/knowledge (T) also expands. Thus, information technology or digital inclusion (DI) has not only brought growth in output per labor but also the employment rate has been stimulated, leading to more inclusive growth.

Following Ali and Son (2007a, b), Anand et al. (2013) developed an integrated measure of inclusive growth by incorporating social mobility function at a macro level that is closely linked to the absolute version of pro-poor growth's definition. Studies have also focused on the endogenous growth model to investigate the significant positive impact of economic freedom on growth and steady-state level of output by controlling the effects of initial output, investment (saving) and population growth rate. As output grows, more employment opportunities are created and hence, inclusive growth emerges. Therefore, growth is the prerequisite for inclusive growth. As population (n) grows, society becomes socially inclusive through media and information technology (Thorat and Dubey 2012). Information technology or digital inclusion (DI) promotes growth in effective per labor and thereby, employment creation, leading to more inclusive growth. If ' $\mathrm{X}$ ' shows the set of control variables, the model can be specified as in Eq. (7).

$$
\mathrm{IG}_{\mathrm{i}, \mathrm{t}}=\alpha_{0}+\delta \mathrm{IG}_{\mathrm{i}, \mathrm{t}-1}+\varphi \mathrm{INS}_{\mathrm{it}}+\theta \mathrm{DI}_{\mathrm{it}}+\gamma \mathrm{SI}_{\mathrm{it}}+\beta \mathrm{X}_{\mathrm{it}}+\varepsilon_{\mathrm{it}}
$$

This study used a set of control variables; inflation, trade openness, investment, education along with institutions as one of the exogenous variables. Based on the theoretical framework an empirical model may be developed as given below to estimate the impact of social inclusion, digital inclusion and institutional quality on inclusive growth in highincome, medium-income and low-income groups of countries:

\footnotetext{
${ }^{4}$ Note that Eqs. 1-6 is designed based upon neo-classical model, which will be added in the SI.
} 


$$
\mathrm{IG}_{\mathrm{i}, \mathrm{t}}=\alpha_{0}+\delta \mathrm{IG}_{\mathrm{i}, \mathrm{t}-1}+\varphi \mathrm{INS}_{\mathrm{it}}+\theta \mathrm{DI}_{\mathrm{it}}+\gamma \mathrm{SI}_{\mathrm{it}}+\beta_{1} \mathrm{TO}_{\mathrm{i}, \mathrm{t}}+\beta_{2} I N V_{\mathrm{i}, \mathrm{t}}+\beta_{3} \mathrm{EDU}_{\mathrm{i}, \mathrm{t}}+\beta_{4} \mathrm{INF}_{\mathrm{i}, \mathrm{t}}+\varepsilon_{\mathrm{i}, \mathrm{t}}
$$

where $I G$ inclusive growth, INS institutional quality, $D I$ digital inclusion, $S I$ social inclusion, INF inflation, TO trade openness, INV investment, EDU education.

In the Eq. (8), $\delta, \varphi, \beta, \theta$ and $\gamma$ refers to the coefficient of inclusive growth(lagged), institutions, control variables, digital inclusion, social inclusion and $\varepsilon$ is for error, $i$ is the number of cross-sections/countries and t shows time in panel data.

Based on the literature reviewed, expected signs of $\varphi, \gamma$ and $\theta$ are positive, as an increase in institutional quality, degree of social and digital inclusivity promotes inclusive growth. According to North (1994) and Aron (2000), effective institutions create a pro-investment environment, promote socio-economic growth and better human resources, which helps to overcome social violence, conflicts and ethnic diversity, etc. and thereby, inclusive growth. Zulfiqar et al. (2016) and Mariana (2014), social inclusion (increased interaction among people) will help the people in learning modes to avoid poverty and hence improve their productive capabilities, eventually leading to inclusive growth. Digital inclusion implies the connectivity of the digital world, people are connected to a new informative system that helps them to avail productive employment opportunities, and hence inclusive growth emerge.

\subsection{Estimation technique and data sources}

To determine the impact of institutions, social inclusion and digital inclusion on inclusive growth, the study has employed a panel data set of 83 countries over the period from 2010 to $2017 .^{5}$ The selected countries are divided into high-income countries (HYCs), middleincome countries (MYCs) and low-income countries (LYCs) based on income levels, following World Bank classification. The social inclusion index (SI) is a composite of eleven variables that are avoidance of homicides, legal rights, financial inclusion, mortality rate, expenditures on health and education, political rights, freedom, GDP growth, school enrollments, life expectancy at birth and in-vulnerable employment. Inclusive growth index is constructed on information about richness, employment to population ratio, income equality and GDP per capita. Digital inclusion index (DI) includes internet users, the number of broadband connections and the number of mobile users. An institutional quality index (INS) is composite of six institutional quality measures; control of corruption (measured by corruption), government effectiveness (measured by bureaucratic quality), rule of law and order, regulatory quality (investment profile), voice and accountability (measured by the military in politics and democratic accountability), political stability and absence of violence (measured by government stability, internal conflict, external conflict, ethnic tensions).

The study applied the min-max normalized indexing technique to construct the indexes for inclusive growth, digital inclusion, social inclusion and institutions. Unlike the present study, most of the studies have used Principle Component Method (PCM) methodology for indexing. The study doesn't employ PCM for two reasons; First, in PCM methodology, the covariance matrix is problematic to be evaluated in an accurate manner (Phillips and Sul 2009) and henceforth it may not be much helpful in conducting comparisons among countries, which was one of the objectives of this study. Second, even the simplest invariance cannot be captured in the PCM index until the training data explicitly provide this

\footnotetext{
${ }^{5}$ The choice of sample is mainly based on the availability of data, particularly on all variables. The available time-period of panel data is 7 (i.e., $\mathrm{T}=7$ ) and $\mathrm{T}<\mathrm{N}$ allows us to successfully implement the system GMM technique.
} 
information ( $\mathrm{Li}$ et al. 2008). Considering this, the benefit of minimum-maximum normalization indexing is that re-scaling widens the range of an indicator, which allows differentiation between countries with similar levels of performances, therefore, more meaningful comparisons can be drawn from the indices.

The data on all economic variables are taken from the World Development Indicators (WDI), published by the World Bank except institutions (ICRG is used). Except for the above-mentioned indices, based on literature, a vector of control variables (X) includes trade openness, investment, education and inflation. Trade openness is the additive of exports and imports divided by the GDP. Inflation is measured by the consumer price index (CPI). Gross fixed capital formation (GFCF) is used as a proxy of investment. The primary education completion rate is used for Education. (Mankiw et al. 1992; Aribah et al. 2016; Siddique et al. 2016; Barro and Lee 1996; Nawaz et al. 2014; Levine and Renelt 1992).

The first generation of growth literature has taken institutions as an exogenous variable. However, since the last decade, it has been widely established that institutions are endogenous factor to economic growth and contributes to the economy by the means of the income level of any country's indicated by Siddique et al. (2016), Acemoglu et al. (2001), Chong and Calderon (2000) and Glaeser et al. (2004). This study treats the lagged value of the dependent variable as an instrument (Blundell and Bond 1998) and institutions are endogenous variables with the dependent variable as inclusive growth. Considering, the issue of endogeneity, the present study applies the most popular technique of the Generalized Method of Moments (GMM). The GMM estimation technique is an extension of Instrumental Variable methodology (IV). The benefit of the GMM estimation technique is that it does not require the model to be serially independent or homoscedastic. Additionally, GMM also takes care of the non-observable country-specific effects, time-series dimension of the data, the inclusion of lagged dependent variables among the independent variables and also caters to the issue of endogeneity (Caselli et al. 1996; Bond et al. 2001). Arellano-Bond test is used to evaluate the second-order serial correlation in differences (Arellano and Bond 1991) and SYS-GMM is employed to establish the robustness of the estimates.

\section{Empirical findings and discussion}

The estimated results of Eq. (8) through SYS-GMM for three groups of countries are reported in Table 1. The reported findings indicate that institutions have played a major role in the achievement of inclusive growth in HYCs, whereas they are insignificant in Low income and middle-income countries. These findings are consistent with the hypothesis that institutional quality plays a crucial role in not only the growth process but also in growth that is inclusive (Acemoglu et al. 2001; Acemoglu et al. 2008; Knack and Keefer 1995; Acemoglu et al. 2006; North 1990; Hall and Jones 1999; Barro 1997; Iqbal and Daly 2014). To examine the role of institutions on inclusive growth at various stages of economic development, the study disaggregates eighty-three countries in HYCs, MYCs and LYCs. Unlike HYCs, the impact of institutions on inclusive growth is not significant in LYCs and MYCs, howsoever, have a positive relationship with inclusive growth in all country sets, which implies that institutions can promote inclusive growth. It might be a result of weaker institutional structure in LYCs and MYCs (Nawaz et al. 2014; Drury et al. 2006; Aidt et al. 2008; Mendez and Sepulveda 2006; Iqbal and Daly 2014), which could be one of the reasons of its insignificant impact on inclusive growth. Zhuang et al. (2010) also indicated that institutions are only effective once they exceeded the world average values. According to OECD (2008), 
Table 1 Determinants of inclusive growth in three income groups of countries using dynamic panel-data estimation, two-step system GMM

\begin{tabular}{|c|c|c|c|}
\hline Variables & HYCs & MYCs & LYCs \\
\hline Inclusive growth (lagged) & $0.458 * * *(0.0541)$ & $0.969 * * *(0.0947)$ & $0.893 * * *(0.0613)$ \\
\hline Institutions & $6.155 * * *(2.21)$ & $0.0493(0.0615)$ & $0.00354(0.237)$ \\
\hline Social inclusion & $0.479 * * *(0.177)$ & $0.106^{* * *}(0.0391)$ & $0.298 * *(0.149)$ \\
\hline Digital inclusion & $0.0318 *(0.0171)$ & $0.00545(0.0116)$ & $0.00382(0.0339)$ \\
\hline Trade openness & $0.0943 * * *(0.0228)$ & $0.0269 *(0.0153)$ & $-0.117(0.0753)$ \\
\hline Investment & $0.0245 *(0.0128)$ & $0.0131 * *(0.00517)$ & $0.0351 *(0.0201)$ \\
\hline Education & $0.0984 * *(0.0461)$ & $0.000694(0.0263)$ & $0.0594(0.0551)$ \\
\hline Inflation & $-0.0013(0.0318)$ & $-0.0114 * *(0.00547)$ & $-0.0436(0.0299)$ \\
\hline Constant & $-22.5(14.73)$ & $-6.296 *(3.387)$ & $-8.896(10.64)$ \\
\hline Number of observations & 174 & 138 & 168 \\
\hline Number of countries & 29 & 23 & 28 \\
\hline Wald $\chi^{2}$ value & 4051.3 & 985.57 & 10755.9 \\
\hline $\operatorname{Prob}>\chi^{2}$ & 0 & 0 & 0 \\
\hline $\begin{array}{l}\text { Arellano-Bond test for AR(2) } \\
\text { in differences ( } p \text { values) }\end{array}$ & 0.713 & 0.75 & 0.188 \\
\hline $\begin{array}{l}\text { Hansen test of joint validity of } \\
\text { instruments ( } p \text { value) }\end{array}$ & 0.881 & 0.908 & 0.935 \\
\hline Hansen test ( $p$ value) & 0.634 & 0.665 & 0.476 \\
\hline
\end{tabular}

Figures in parentheses are standard errors from two-step system GMM

$* * *, * *$, and *represent significance levels of $1 \%, 5 \%$ and $10 \%$ respectively

inclusive and non-extractive institutions always promote inclusive growth. In LYCs, the institutional structure transcends into 'extractive political institutions' and hence not contributing significantly to the promotion of inclusive growth in these societies. These findings support the findings of an earlier study by Mohommad et al. (2012). Contribution of the variable of institutional quality is significantly positive only in HYCs that practice inclusive and non-extractive institutions as compare to the remaining two groups. The results are akin to the findings of Fearon (2003). Chu (2001) and Aron (2000).

Empirical results of the study report that the most contributing factor in inclusive growth is social inclusion prevailing in the countries. Correspondingly, a higher degree of social inclusivity in these societies further helps to promote inclusive growth. It is imperative to note that the social inclusion index has included financial inclusion as one of its main components. Thus, social inclusion resulting from financial inclusion is an important determinant of inclusive growth in these nations. Besides, the results coincide with the findings of Zulfiqar et al. (2016). Another strand of social inclusivity advocates that increased interaction among people helped the people in learning modes to avoid poverty and enhance their productive capabilities, eventually leading to inclusive growth (UN-DESA 2009). The results indicate a positive impact of social inclusion on inclusive growth in all country sets, but its contribution is relatively high in HYCs than in MYCs and LYCs. The lower contribution of social inclusion to inclusive growth in MYCs and LYCs could be attributed to several reasons. First, digital inclusion is at the peak in HYCs, which makes them more socially inclusive as well. Second, the flow of knowledge, literacy and social capital is also high in HYCs, as compared to MYCs and LYCs, which makes them comparatively more socially inclusive. Another intuition about the study's result is, LYCs have a higher degree of collaboration with the world than MYCs and LYCs, which is the reason for social inclusion not to contribute significantly to the inclusive growth of LYCs and MYCs. 
Fig. 6 Presentation of Venn diagram. Source: Developed by the Authors

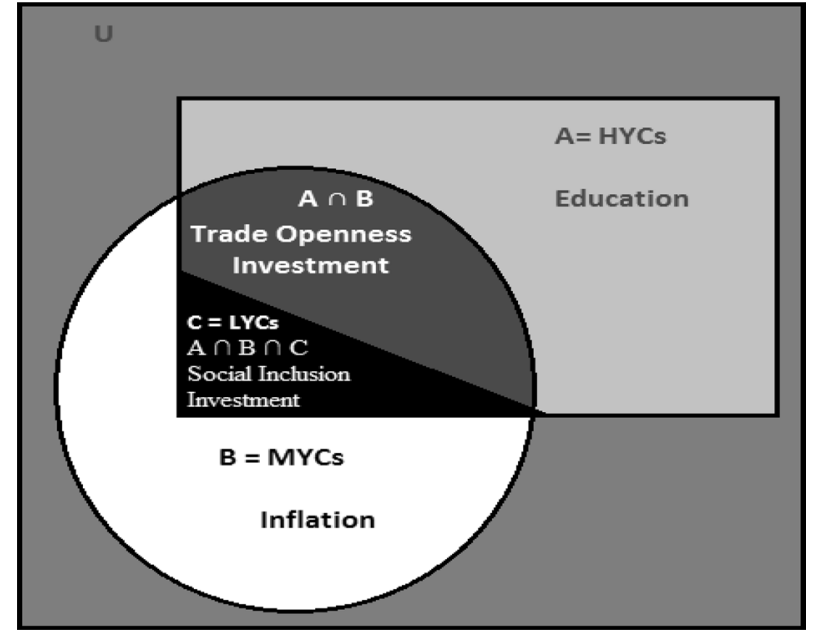

The reasons might be, MYCs are still far away from HYCs, so they cannot be much helpful for LYCs, hence both LYCs and MYCs are more interested in collaborations with HYCs.

The digital inclusion has positively and significantly contributed to inclusive growth in only HYCs because digital inclusion is widely spread and affordable in the high-income countries only. These empirical findings are in line with the study of McKinsey Global Institute (2016). The large and significant co-efficient of digital inclusion in HYCs indicates that the large magnitude of digital inclusion has an insignificant impact on inclusive growth, which are promising results. The intuitions behind such results are that the majority of residents of HYCs are well interconnected due to digital/internet facilities, which facilitate them in getting new information and earn productive employment opportunities. Digital inclusion is insignificant in MYCs and LYCs, but has positive linkage with inclusive growth, which explains that digital inclusion if ensured at a level of HYCs can open tremendous windows of new learning opportunities.

The estimated coefficients of control variables indicate that trade openness has a significant positive impact on the inclusive growth of sample countries in HYCs and MYCs. However, the magnitude of this impact is larger in HYCs as compared to that of MYCs Investment has a significant impact on inclusive growth in all data sets, however, the coefficient is strongest in LYCs, followed by HYCs and MYCs. Investment has the strongest co-efficient in LYCs since the rate of growth of investment is higher in LYCs, which results in higher inclusive growth. These findings are matching with existing literature (Rebelo 1991; Barro 1991). Inflation has negative associations with inclusive growth, implying that inflation hurts the inclusive growth process causing uncertainty in the economy coupled with lower productivity. The result is consistent with the other studies (Nawaz et al. 2014; Sirimaneetham and Temple 2009; Fischer 1993). Education has a positive impact on inclusive growth; however, it is only significant in HYCs. The reason is that there is a higher literacy level in HYCs, and it is more promising towards inclusive growth in HYCs, than MYCs and LYCs (Aslam and Zulfiqar 2016). The insignificance of it might be the result of poor quality of education and health facilities prevailing in these countries, as these economies hardly spend $2 \%$ or less of their GDP on these facilities. The diagnostic checks show that the $p$ value of $\operatorname{AR}(2)$ is insignificant for three income countries, whereas the $p$ value of the Sargan/Hansen test is 
also insignificant in all three income countries, which is desirable. Thus, it can be safely concluded that there is no autocorrelation and problem of endogeneity in the model.

The results of the study are also represented in the Venn diagram as shown in Fig. 6. Figure 6 displays that the significance of variables increases as economies move toward inclusive growth (LYCs to MYCs and HYCs). The significant variables shown in Table 1, relevant to all three income countries are shown by three sets; A, B and C indicate HYCs, MYCs and LYCs, respectively.

$\mathrm{U}=\{$ Institutions, Social Inclusion, Digital Inclusion, Trade openness, Investment, Inflation, Education $\}$

$A=\{$ Institutions, Social Inclusion, Digital Inclusion, Trade openness, Investment, Education $\}=$ HYCs

$\mathrm{B}=\{$ Social Inclusion, Inflation, Trade openness, Investment $\}=$ MYCs

$\mathrm{C}=\{$ Social Inclusion, Investment $\}=\mathrm{LYCs}$

$$
\begin{gathered}
\mathrm{B}-\mathrm{C}=\mathrm{U}-\left(\mathrm{C}^{\prime} \mathrm{U}(\mathrm{B} \cap \mathrm{C})=\{\text { Inflation, Trade openness }\}\right. \\
\mathrm{A} \cap(\mathrm{B} \cap \mathrm{C})=\{\text { Social Inclusion, Investment }\} \\
\mathrm{A}-(\mathrm{B} \mathrm{U} \mathrm{C})=\{\text { Social Inclusion, Trade openness, Investment }\} \\
\mathrm{A} \cap \mathrm{B} \cap \mathrm{C} \\
\mathrm{A} \cap \mathrm{B}
\end{gathered}
$$

The results of the study conclude that all determinants have a significant contribution to inclusive growth, except inflation. The number of significant variables decreases as there is a transition from HYCs to MYCs and LYCs. In MYCs, four variables out of eight have a significant effect on inclusive growth and only two out of eight are significant in the case of LYCs. The interesting finding of this study is that institutions are only significant in HYCs with the highest value of co-efficient. However, they are playing a positive role in other income groups too. Therefore, the imperative constituent towards inclusive growth is 'institutions' and it should be focused by MYCs and LYCs countries if they want to catch up to the level of inclusive growth prevailing in HYCs. Regarding social and digital inclusion, there seem to be no doubts that inclusive growth requires rigorous investments to embrace digital and social inclusion in all three income groups. The key to tomorrow's inclusive growth lies in formulating a cohort policy framework for socio-digital inclusion.

\section{Conclusions and policy implications}

A major portion of the literature on determinants of inclusive growth is based on casual empiricism and few have investigated the role of socio-digital inclusion in the presence of existing institutional structure that is the primary driving factor of inclusive growth. The main objective of the study was to estimate the contribution of socio-digital inclusivity and institutions towards inclusive growth in three income groups along with the composition of indexes for the same. This study addresses the issue of endogeneity by using system GMM procedure for the panel of 83 countries (divided into three income groups; HYCs, MYCs and LYCs) for the period from 2010 to 2017. Min-max normalized indexing technique was used to construct inclusive growth index, social inclusion, digital inclusion and institutional quality index. Countries ranking based on the value of these two indices indicate that almost countries practicing a higher degree of institutional quality are also enjoying the fruits of inclusive growth. However, there is a need to further strengthen institutions and their structure in the low and middle-income counties. 
The basic research question focused was "Does socio digital inclusion helps in inclusive growth in three income countries". The results show promising results of digital, social inclusion and institutions for embracing inclusive growth. It was also seen that countries with low inclusive growth can follow the pathways of middle- and high-income groups to achieve inclusive growth. The Hypothesis of inclusion Differences were also found to be true, positing that high, middle- and low-income countries differ in their levels of social inclusion, digital inclusion and inclusive growth, owing to their institutional structure. This inclusive growth comparison Hypothesis holds as well. It posits that achievement in inclusive growth varies among different income groups. High-income countries have higher inclusive growth than countries with low-income levels. The third Hypothesis of Jeopardy also holds. This hypothesis states that low-income countries were found to be more vulnerable to the harms in terms of low inclusive growth and require a pathway to achieve inclusive growth by learning from countries enjoying higher inclusive growth.

Estimated results of the study recommended the positive role of institutional quality, social inclusion, digital inclusion, trade openness, investment and education in promoting inclusive growth in HYCs. The results are much owing to the strong institutional structure in these countries with planned policies towards growth that is inclusive. In MYCs and LYCs, the contribution of institutional quality is not strong, due to its prevailing poor quality of law and order, justice, bureaucratic quality, governance and poor control on corruption in these nations. Social inclusivity has positively contributed to inclusive growth in all three income groups, whereas digital inclusion only in HYCs. It is also important to note that social inclusion may not be disabled in the current times and socio-digital inclusion must be kept in focus of policy formulators for achieving inclusive growth. Inflation seemed to be only significant in MYCs groups, particularly because of controlling inflation in these countries have brought significant results in improving inclusive growth. On the other hand, in LYCs, inflation is double-digit in most of the countries and hardly ever was contributing towards the process of inclusive growth. Inflation (showing weak fiscal policies or weak institutions) mostly affects the power of inclusive growth, in these countries.

Empirical findings of the study strongly support that institutional quality should be the focus of the public policy designers and economic managers of MYCs and LYCs, to turn economic growth more inclusive in these economies. Policies options to improve bureaucratic quality, law and order situations and control on corruption must be prioritized by policymakers. Besides, digital and social inclusivity should be another target of policies designer to accelerate the pace of inclusive growth in MYCs and LYCs. Institutions are comprised of social norms and regulations, which play a significant role in ensuring social inclusion. Therefore, improvement in regulatory laws and socio-cultural traits through human capital development (education and health) can play an imperative role in achieving the desired goal.

\section{Limitations and scope for future research}

The data sample used in the study covers eighty-four countries based on the availability of data series for forty-six determinants. It would be better if more countries can be added in the sample in the future provided the data availability, especially on poverty and income inequalities. Hence, one can say that it is still the initial stage of research in this direction. The study has looked into the impacts of different income countries for three major sets. For future research, a similar reach and approach can be extended to analyze specific regions and even at the sector level to formulate the policies to address the regional differences and individual sector performance, subject to the sufficient data availability to meet quantitative and econometric requirements to draw results. 


\section{Appendix}

See Tables 2, 3.

Table 2 World ranking on the bases of inclusive growth Index. Source: Constructed by the Authors

\begin{tabular}{|c|c|c|c|c|c|c|c|}
\hline Rank & Country & IGI & Category & Rank & Country & IGI & Category \\
\hline 1 & Norway & 84.34 & HYC & 43 & Japan & 56.1 & HYC \\
\hline 2 & Iceland & 79.76 & HYC & 44 & Argentina & 55.99 & MYC \\
\hline 3 & $\begin{array}{l}\text { Luxem- } \\
\text { bourg }\end{array}$ & 78.11 & HYC & 45 & Indonesia & 55.25 & LYC \\
\hline 4 & Netherland & 76.49 & HYC & 46 & Chile & 55.24 & HYC \\
\hline 5 & Sweden & 75.8 & HYC & 47 & Bulgaria & 54.55 & MYC \\
\hline 6 & Denmark & 75.39 & HYC & 48 & Mexico & 54.54 & MYC \\
\hline 7 & Austria & 73.27 & HYC & 49 & Bolivia & 54.52 & LYC \\
\hline 8 & Finland & 71.7 & HYC & 50 & Armenia & 54.46 & LYC \\
\hline 9 & USA & 70.7 & HYC & 51 & Lebanon & 54.32 & MYC \\
\hline 10 & Kazakhstan & 70.5 & MYC & 52 & Iraq & 53.99 & MYC \\
\hline 11 & Belgium & 69.58 & HYC & 53 & Panama & 53.69 & MYC \\
\hline 12 & Ireland & 69.08 & HYC & 54 & Pakistan & 53.52 & LYC \\
\hline 13 & England & 69.05 & HYC & 55 & Paraguay & 53.32 & MYC \\
\hline 14 & Czech Rep. & 68.2 & HYC & 56 & South Africa & 53.17 & MYC \\
\hline 15 & Slovenia & 67.6 & HYC & 57 & Uganda & 52.96 & LYC \\
\hline 16 & Australia & 66.32 & HYC & 58 & Kyrg & 52.88 & LYC \\
\hline 17 & Belarus & 65.88 & MYC & 59 & Russia & 52.72 & MYC \\
\hline 18 & Slovakia & 65.34 & HYC & 60 & Egypt & 52.66 & LYC \\
\hline 19 & Cyprus & 64.83 & HYC & 61 & Ecuador & 52.55 & MYC \\
\hline 20 & Thailand & 64.47 & MYC & 62 & Brazil & 51.7 & MYC \\
\hline 21 & Nepal & 63.8 & LYC & 63 & Korea, Rep. & 51.45 & HYC \\
\hline 22 & Vietnam & 63.63 & LYC & 64 & Bangladesh & 51.23 & LYC \\
\hline 23 & Estonia & 63.21 & HYC & 65 & Rwanda & 51.18 & LYC \\
\hline 24 & Romania & 62.36 & MYC & 66 & Moldova & 50.74 & LYC \\
\hline 25 & Poland & 61.29 & HYC & 67 & Tanzania & 50.55 & LYC \\
\hline 26 & Portugal & 60.8 & HYC & 68 & Iran & 50.32 & MYC \\
\hline 27 & Ukraine & 60.76 & LYC & 69 & India & 50.24 & LYC \\
\hline 28 & Malaysia & 60.45 & MYC & 70 & Colombia & 49.55 & MYC \\
\hline 29 & Italy & 60.27 & HYC & 71 & Morocco & 49.02 & LYC \\
\hline 30 & Hungary & 60.25 & HYC & 72 & Algeria & 48.7 & MYC \\
\hline 31 & Spain & 59.77 & HYC & 73 & Sri Lanka & 48.13 & LYC \\
\hline 32 & Lithuania & 59.75 & HYC & 74 & Yemen, Rep. & 47.71 & LYC \\
\hline 33 & Azerbaijan & 59.33 & MYC & 75 & Turkey & 45.72 & MYC \\
\hline 34 & Latvia & 59.3 & HYC & 76 & Jordan & 45.63 & LYC \\
\hline 35 & Uruguay & 59.02 & HYC & 77 & Tunisia & 44.07 & LYC \\
\hline 36 & Peru & 58.53 & MYC & 78 & Togo & 43.62 & LYC \\
\hline 37 & China & 58.52 & MYC & 79 & Honduras & 43.4 & LYC \\
\hline 38 & Ghana & 57.97 & LYC & 80 & Malawi & 42.62 & LYC \\
\hline 39 & Philippines & 57.26 & LYC & 81 & Madagascar & 41.75 & LYC \\
\hline 40 & Zimbabwe & 57.13 & LYC & 82 & Nigeria & 34.58 & LYC \\
\hline 41 & Georgia & 56.68 & LYC & 83 & Uzbekistan & 32.38 & LYC \\
\hline 42 & Croatia & 56.61 & MYC & & & & \\
\hline
\end{tabular}


Table 3 World ranking on the Bases of institutional quality Index. Source: Constructed by the Authors

\begin{tabular}{|c|c|c|c|c|c|c|c|}
\hline Rank & Country & IQI & Category & Rank & Country & IQI & Category \\
\hline 1 & Finland & 94.62 & HYC & 43 & Ghana & 59.7 & LYC \\
\hline 2 & Norway & 93.74 & HYC & 44 & Brazil & 59 & MYC \\
\hline 3 & Sweden & 93.12 & HYC & 45 & Jordan & 58.6 & LYC \\
\hline 4 & Luxembourg & 93.01 & HYC & 46 & Tunisia & 54.7 & LYC \\
\hline 5 & Netherland & 91.2 & HYC & 47 & Indonesia & 54.3 & LYC \\
\hline 6 & Australia & 90.32 & HYC & 48 & Ukraine & 54.1 & LYC \\
\hline 7 & Iceland & 89.58 & HYC & 49 & Honduras & 54 & LYC \\
\hline 8 & England & 88.88 & HYC & 50 & Colombia & 53.8 & MYC \\
\hline 9 & Denmark & 88.3 & HYC & 51 & Tanzania & 52.4 & LYC \\
\hline 10 & Austria & 87.93 & HYC & 52 & Uzbekistan & 52.2 & LYC \\
\hline 11 & Ireland & 86.86 & HYC & 53 & Malawi & 52.2 & LYC \\
\hline 12 & Belgium & 86.28 & HYC & 54 & Kyrg & 50.6 & LYC \\
\hline 13 & USA & 84.24 & HYC & 55 & Kazakhstan & 49.9 & MYC \\
\hline 14 & Japan & 84.14 & HYC & 56 & Algeria & 49.9 & MYC \\
\hline 15 & Cyprus & 81.78 & HYC & 57 & Lebanon & 49.6 & MYC \\
\hline 16 & Poland & 80.69 & HYC & 58 & Sri Lanka & 48.6 & LYC \\
\hline 17 & Slovakia & 77.78 & HYC & 59 & Nepal & 48.3 & LYC \\
\hline 18 & Portugal & 77.47 & HYC & 60 & Bangladesh & 48.3 & LYC \\
\hline 19 & Chile & 76.65 & HYC & 61 & Bolivia & 47.7 & LYC \\
\hline 20 & Hungary & 76.24 & HYC & 62 & Vietnam & 47.6 & LYC \\
\hline 21 & Czech Republic & 75.46 & HYC & 63 & Moldova & 47.4 & LYC \\
\hline 22 & Spain & 75.33 & HYC & 64 & Thailand & 47.1 & MYC \\
\hline 23 & Estonia & 73.57 & HYC & 65 & Iran & 47.1 & MYC \\
\hline 24 & Italy & 72.9 & HYC & 66 & Turkey & 45.9 & MYC \\
\hline 25 & Slovenia & 72.85 & HYC & 67 & Armenia & 44.3 & LYC \\
\hline 26 & Croatia & 71.86 & MYC & 68 & Russian Federation & 43.7 & MYC \\
\hline 27 & Korea, Rep. & 71.82 & HYC & 69 & China & 42.6 & MYC \\
\hline 28 & Lithuania & 71 & HYC & 70 & Pakistan & 41.9 & LYC \\
\hline 29 & Panama & 69.7 & MYC & 71 & Uganda & 41.8 & LYC \\
\hline 30 & Uruguay & 68.48 & HYC & 72 & Ecuador & 41.4 & MYC \\
\hline 31 & Latvia & 68.34 & HYC & 73 & Madagascar & 40.7 & LYC \\
\hline 32 & Rwanda & 67.9 & LYC & 74 & Georgia & 39.9 & LYC \\
\hline 33 & Bulgaria & 67.02 & MYC & 75 & Azerbaijan & 39.7 & MYC \\
\hline 34 & Malaysia & 66.59 & MYC & 76 & Yemen, Rep. & 38.4 & LYC \\
\hline 35 & India & 65.61 & LYC & 77 & Belarus & 38.2 & MYC \\
\hline 36 & South Africa & 64.38 & MYC & 78 & Nigeria & 37.7 & LYC \\
\hline 37 & Romania & 62.3 & MYC & 79 & Paraguay & 37.3 & MYC \\
\hline 38 & Philippines & 62.00 & LYC & 80 & Egypt & 36.9 & LYC \\
\hline 39 & Mexico & 61.34 & MYC & 81 & Iraq & 35.4 & MYC \\
\hline 40 & Argentina & 61.31 & MYC & 82 & Togo & 27.9 & LYC \\
\hline 41 & Morocco & 60.41 & LYC & 83 & Zimbabwe & 27.8 & LYC \\
\hline 42 & Peru & 60.12 & MYC & & & & \\
\hline
\end{tabular}




\section{References}

Abosede, A.J., Onakoya, A.B.: Entrepreneurship, economic development and inclusive growth. Int. J. Arts Entrep. 1(3), 375-387 (2013)

Acemoglu, D., Robinson, J.A.: Why Nations Fail: The Origins of Power, Prosperity, and Poverty. Crown Business, London (2012)

Acemoglu, D., Johnson, S., Robinson, J.A.: The colonial origins of comparative development: an empirical investigation. Am. Econ. Rev. 91(5), 1369-1401 (2001)

Acemoglu, D., Cutler, D., Finkelstein, A., Linn, J.: Did medicare induce pharmaceutical innovation? Am. Econ. Rev. 96(2), 103-107 (2006)

Acemoglu, D., Johnson, S., Robinson, J.A., Yared, P.: Income and democracy. Am. Econ. Rev. 98(3), 808842 (2008)

Aidt, T., Dutta, J., Sena, V.: Governance regimes, corruption and growth: theory and evidence. J. Comp. Econ. 36, 195-220 (2008). https://doi.org/10.1016/j.jce.2007.11.004

Aizeman, J., Lee, M. and Park, D. (2012). The relationship between structural change and inequality: A conceptual overview with special reference to developing Asia, ADBI Working Paper 396, Asian Development Bank Institute, Tokyo.

Alesina, A., Rodrik, D.: Distributive politics and economic growth. Q. J. Econ. 109(2), 465-490 (1994)

Ali, I., Son, H.: Defining and measuring inclusive growth: application to the Philippines. ERD Working Paper 99, Economics and Research Department, Asian Development Bank, Manila (2007a)

Ali, I., Son, H.: Measuring inclusive growth. Asian Dev. Rev. 24(1), 11-31 (2007)

Ali, I., Yao, X.: Pro-poor inclusive growth for sustainable poverty reduction in developing Asia: The enabling role of infrastructure development. ERD Policy Brief Series No. 27. ADB (2004)

Anand, R., Mishra, S., Peiris, S.J.: Inclusive growth: measurement and determinants. Washington, DC. (IMF Working Paper No. 135) (2013)

Aron, J.: Growth and institutions: a review of the evidence. World Bank Res. Obs. 15(1), 99-135 (2000)

Arellano, M., Bond, S.: Some tests of specification for panel data: Monte Carlo evidence and an application to employment equations. Rev. Econ. Stud. 58, 277-297 (1991)

Asian Development Bank (ADB):: Asian Development Outlook 2012 Confronting Rising Inequality in Asia. Manila (2012)

Aslam, A.: The hotly debate of human capital and economic growth: Why institutions may matter? Qual. Quant. Int. J. Meth.(2020). https://doi.org/10.1007/s11135-020-00989-5

Aslam, A., Zulfiqar, K.: Policy framework for inclusive growth: a case study of selected Asian countries. Forman J. Econ. Stud. 12, 21-40 (2016)

Aslam, A., Sultana, N., Yasin, I.: Bi-directional associations among educational quality, institutions and social inclusion: SEM analysis. Pak. Econ.Soc. Rev. 55(2), 445-462 (2017)

Bach, A., Shaffer, G., Wolfson, T.: Digital human capital: developing a framework for understanding the economic impact of digital exclusion in low-income communities. J. Inf. Policy 3, 247-266 (2013). https://doi.org/10.5325/jinfopoli.3.2013.0247

Barro, R.J.: Economic growth in a cross section of countries. Q. J. Econ. 106(2), 407-443 (1991)

Barro, R.J.: Determinants of Economic Growth: A Cross-Country Empirical Study. MIT Press, Cambridge (1997)

Barro, R.J., Lee, J.W.: International Measures of schooling years and schooling quality. Am. Econ. Rev. 86(2), 218-223 (1996)

Berg, A., Ostry, J.D.: Inequality and Unsustainable Growth: Two Sides of the Same Coin?” IMF Staff Discussion Note 11/08. International Monetary Fund, Washington (2011)

Bhalla, S.S., Das, T.: Pre- and post-reform India: a revised look at employment, wages and inequality. India Policy Forum 2005-06, 183-253 (2007)

Blundell, R., Bond, S.: Initial conditions and moment restrictions in dynamic panel data models. J. Econ. 87(1), 115-143 (1998)

Bolt, R.: Accelerating agriculture and rural development for inclusive growth: policy implementation. ERD Policy Brief Series No. 29. ADB, Manila (2004)

Bond, S., Bowsher, C., Windmeijer, F.: Criterion-based inference for GMM in autoregressive panel data models. Econ. Lett. 73(3), 379-388 (2001)

Bourguignon, F., Morrisson, C.: Income distribution, development and foreign trade: a cross-sectional analysis. DELTA Working Papers, 89-05 (1989)

Caselli, F., Esquivel, G., Lefort, F.: Reopening the convergence debate: a new look at cross-country growth empirics. J. Econ. Growth 1(3), 363-389 (1996)

Chong, A., Calderon, C.: Causality and feedback between institutional measures and economic growth. Econ. Polit. 12(1), 69-81 (2000) 
Chu, K.-y.: Collective values, behavioral norms, and rules: building institutions for economic growth and poverty reduction. WIDER Discussion Paper (WDP 2001/98) (2001)

Corbi, R.B.: The components of economic freedom, income and growth: an empirical analysis. Estudos Econômicos (São Paulo) 37(3), 515-545 (2007)

de Haan, A., Throat, S.: Inclusive growth: more than safety nets. IDRC/CRDI SIG Working Paper (2013)

Deininger, K., Squire, L.: Measuring income inequality: a new data-base. Papers 537, Harvard Institute for International Development (1996)

Deininger, K., Squire, L.: New ways of looking at old issues: inequality and growth. J. Dev. Econ. 57(2), 259-287 (1998)

DESA.: Creating an inclusive society: practical strategies to promote social integration (2009). Archived from http://www.un.org/esa/socdev/egms/docs/2009/Ghana/inclusive-society.pdf

Dias, M.: Education, development and social inclusion in portugal: policies, processes and results. Procedia Soc. Behav. Sci. 116, 1864-1868 (2014)

Djankov, S., Glaeser, E., La Porta, R., Lopez-de-Silanes, F., Shleifer, A.: The new comparative economics. J. Comp. Econ. 31(4), 595-619 (2003)

Dollar, D., Kraay, A.: Growth is good for the poor. J. Econ. Growth 7, 195-225 (2002)

Drury, A., Krieckhaus, J., Lusztig, M.: Corruption, democracy, and economic growth. Int. Political Sci. Rev. 27, 121-136 (2006). https://doi.org/10.1177/0192512106061423

Easterly, W., Woolcock, M., Ritzen, J.: Social cohesion, institutions, and growth. Econ. Polit. 18, 103120 (2006). https://doi.org/10.2139/ssrn.983117

Faundez, J.: Douglass North's theory of institutions: lessons for law and development. Hague J. Rule Law 8(2), 373-374 (2016)

Fearon, J.D.: Ethnic and cultural diversity by country. J. Econ. Growth 8(2), 195-222 (2003)

Fernando, N.: Rural Development Outcomes and Drivers: An Overview and Some Lessons. EARD Special Studies, ADB, Manila (2008)

Fischer, S.: The role of macroeconomic factors in growth. J. Monetary Econ. 32(3), 485-512 (1993). https:// EconPapers.repec.org/RePEc:eee:moneco:v:32:y:1993:i:3:p:485-512.

Flynn, P.J., Scruggs, T., Bowyer, K.W., Chang, J., Hoffman, K., Marques, J., Min, J., Worek, W.: Overview of the face recognition grand challenge. In: IEEE Computer Society Conference on Computer Vision and Pattern Recognition 2005. CVPR 2005, pp. 947-954 (2005)

Forbes, K.: A reassessment of the relationship between inequality and growth. Am. Econ. Rev. 90(4), 869-887 (2000)

Glaeser, E. L., Rafael La Porta, Florencio Lopez-de-Silanes and Andrei Shleifer.: Do institutions cause growth? J. Econ. Growth v9(3), 271-303 (2004)

Goudie, A., Ladd, P.: Economic growth, poverty and inequality. J. Int. Dev. 11, 177-195 (1999)

Habito, C.F.: Patterns of inclusive growth in developing Asia: insights from an enhanced growth-poverty elasticity analysis. ADBI Working Paper 145 (2009)

Hall, R.E., Jones, C.I.: Why do some countries produce so much more output per worker than others? Q. J. Econ. 114(1), 83-116 (1999)

Hausmann, R., Hidalgo, C., Stock, D., Yildirim, M.: Implied Comparative Advantage. SSRN Electronic Journal (2014). https://doi.org/10.2139/ssrn.2410427

Ianchovichina, E., Lundstrom, S.: Inclusive growth analytics: framework and application. Policy Research Working Paper Series 4851 (2009)

IMF (International Monetary Fund).: Regional economic outlook: Asia and Pacific. October, Washington, DC (2011)

Iqbal, N., Daly, V.: Rent seeking opportunities and economic growth in transitional economies. Econ. Model. 37, 16-22 (2014). https://doi.org/10.1016/j.econmod.2013.10.025

Jin, D.: Smartland Korea: mobile communication, culture, and society. Ann Arbor: University of Michigan Press (2017). Retrieved May 7, 2020, from www.jstor.org/stable/10.3998/mpub.9332315

Kaufmann, D., Kraay, A., Zoido-Lobaton, P.: Governance matters II: updated indicators for 2000-01. Policy Research Working Paper No. 2772 (2002)

Kim, H., Qureshi, Z. (Eds.): Growth in a time of change: global and country perspectives on a new agenda. Washington, D.C.: Brookings Institution Press (2020). https://doi.org/10.7864/j.ctvbn $\mathrm{m} 3 \mathrm{pb}$

Klonowska, K., Bindt, P.: (Rep.) Hague Centre for strategic studies (2020). https://doi.org/10.2307/resre p24004

Knack, S., Keefer, P.: Instutions and economic performance: cross-country test using alternative institutional measures. Econ. Polit. 7(3), 207-227 (1995)

Kraay, A.: When is growth pro-poor? Evidence from a Panel of Countries. The World Bank, Policy Research Working Paper No. 3225 (2004) 
Kuznets, S.: Economic growth and income inequality. Am. Econ. Rev. 45, 1-28 (1955)

Levine, R., Renelt, D.: A sensitivity analysis of cross-country growth regressions. Am. Econ. Rev. 82(4), 942-963 (1992)

Li, C., Diao, Y., Ma, H., Li, Y.: A statistical PCA method for face recognition. In: Intelligent Information Technology Application, 2008, pp. 376-380 (2008)

Lin, Y.J.: Development strategies for inclusive growth in developing asia. Paper presented for Asian development bank's distinguished speakers program. Manila (2004)

López, H.: Pro-poor growth: a review of what we know (and of what we don't). Manila (2004)

Mankiw, N.G., Romer, D., Weil, D.N.: A contribution to the empirics of economic growth. Q. J. Econ. 107(2), 407-437 (1992)

Mariana, D.: Education, development and social inclusion in Portugal: policies, processes and results. Procedia - Soc. Behav. Sci. 116, 1864-1868 (2014)

McKinsey Global Institute (2016) Digital finance for all: powering inclusive growth in emerging economies

McKinley, T.: Inclusive growth criteria and indicators: an inclusive growth index for diagnosis of country progress. ADB Sustainable Development Working Paper Series, No. 14. Mandaluyong City, Philippines, Asian Development Bank (2010)

Mendez, F., Sepulveda, F.: Corruption, growth and political regimes: Cross country evidence. European J. Political Econ. 22(1), 82-98 (2006)

Meschi, E., Vivarelli, M.: Globalisation and income inequality. (Discussion Paper No. 2958) (2007)

Mohommad, A., Singh, A., Jain-Chandra, S.: Inclusive growth, institutions, and the underground economy. IMF working papers, Working Paper No. 12/47.ISBN/ISSN:9781463937089/1018-5941 (2012)

Mutsvairo, B., Ragnedda, M. (eds.): Mapping Digital Divide in Africa: A Mediated Analysis. Amsterdam University Press, Amsterdam (2019). https://doi.org/10.2307/j.ctvh4zj72

Narayan, D.: Voices of the poor: poverty and social capital in Tanzania. Environmentally Sustainable Development Monograph 20. World Bank, Washington, D.C (1997)

Nawaz, S.: Growth Effects of Institutions: A Disaggregated Analysis. COMSATS Institute of Information Technology, Islamabad (2014)

Nawaz, S., Iqbal, N., Khan, M.: The impact of institutional quality on economic growth: panel evidence. Pak. Dev. Rev. 53, 15-31 (2014). https://doi.org/10.30541/v53i1pp.15-31

North, D.C.: Institutions, institutional change and economic performance. Cambridge University Press, Cambridge (1990)

North, D.C.: Economic performance through time. Am. Econ. Rev. 84, 359-368 (1994)

North, D.C., Davis, L.: Institutional change and American economic growth (1970)

OCGD (Commission on Growth and Development): The Growth Report: Strategies for Sustained Growth and Inclusive Development. The World Bank Group, Washington DC (2008)

Parrott, S., Aron-Dine, A., Leachman, M., Stone, C., Rosenbaum, D., Pavetti, L., Romig, K.: (Rep.). Center on Budget and Policy Priorities (2020). https://doi.org/10.2307/resrep23735

Perch, L.: Mitigation of what and by what? Adaptation by whom and for whom? Dilemmas in delivering for the poor and the vulnerable in international climate policy. Working Paper No. 79. Brasilia, Brazil: International Policy Centre for Inclusive Growth (2011)

Phillips, P., Sul, D.: Economic transition and growth. J. Appl. Econ. 24(7), 1153-1185 (2009). Retrieved June 23, 2020, from https://www.jstor.org/stable/25608787

Pitakdumrongkit, K.: Addressing digital protectionism in Asean: towards better regional governance in the digital age (pp. 3-4, Rep.). S. Rajaratnam School of International Studies (2018). Retrieved May 7, 2020, from www.jstor.org/stable/resrep17645.5

Przeworski, A.: The last instance: are institutions the primary cause of economic development? Eur. J. Sociol. 45(2), 165-188 (2004)

Qian, J.: Dealing with endogeneity (2014). http://jhqian.org/ec310/06endogeneity.pdf

Ragnedda, M.: Conceptualising the digital divide. In: Ragnedda, M., Mutsvairo, B. (eds.) Mapping Digital Divide in Africa: A Mediated Analysis, pp. 27-44. Amsterdam University Press, Amsterdam (2019). https://doi.org/10.2307/j.ctvh4zj72.6

Rauniyar, G., Kanbur, R.: Inclusive growth and inclusive development: a review and synthesis of Asian development bank literature. J. Asia Pacific Econ. 15(4), 455-469 (2010). https://doi. org/10.1080/13547860.2010.517680

Ravallion, M.: Inequality convergence. Policy Research Working Paper; No. 2645. World Bank, Washington, DC (2001)

Ravallion, M., Chen, S.: Measuring pro-poor growth. Econ. Lett. 78(1), $93-99$ (2003)

Rebelo, S.: Long-run policy analysis and long-run growth. J. Polit. Econ. 99(3), 500-521 (1991)

Richardson, G., Bogart, D.: Making property productive: reorganizing rights to real and equitable estates in Britain. Eur. Rev. Econ. Hist. 13, 3-30 (2009) 
Saad Filho, A.: From Washington Consensus to Inclusive Growth: The Continuing Relevance of Pro-Poor Policy Alternatives, World Economic and Social Survey (2010)

Sachs, J.D., Warner, A., Åslund, A., Fischer, S.: Economic reform and the process of global integration. Brookings Papers on Economic Activity, 1-118 (1995)

Saima, A., Javed, S.A.: On measuring inclusiveness of growth in Pakistan: the Pakistan development review. Pak. Inst. Dev. Econ. 50(4), 879-894 (2011)

Shirley, M.M.: Institutions and development. In: Ménard, Claude, Shirley, Mary M. (eds.) Handbook of New Institutional Economics, pp. 611-638. Springer, Dordrecht (2005)

Shirley, M.M.: Institutions and Development. Edward Elgar, Cheltenham (2008)

Siddique, H.M.A., Nawaz, A., Majeed, M.T.: The impact of institutional governance on economic growth: a panel data analysis. Bulletin (2016)

Silver, H.: Social exclusion and social solidarity: three paradigms. Int. Labor Rev. 133(5-6), 531-578 (1994)

Sirimaneetham, V., Temple, J.R.W.: Macroeconomic stability and the distribution of growth rates. World Bank Econ. Rev. 23(3), 443-479 (2009)

Solow, R.M.: A contribution to the theory of economic growth. Q. J. Econ. 70, 65-94 (1956)

Tandon, A., Zhuang, J.: Inclusiveness of economic growth in the People's Republic of China: What do population health outcomes tell us? ERD Policy Brief Series No. 47, Economics and Research Department, Asian Development Bank, Manila (2007)

Thorat, S., Dubey, A.: Has growth been socially inclusive during 1993-94-2009-10? Econ. Polit. Weekly 47, 43-53 (2012)

Tripathi, S.: Does higher economic growth reduce poverty and increase inequality? Evidence from urban India. Indian J. Hum. Dev. 7, 109-137 (2013)

UN/DESA (United Nations Department of Economic and Social Affairs): World Economic Situationand Prospects. UN/DESA, New York (2012)

Wallcook, S., Morris, K.: Supporting digital health and digital inclusion: an occupational therapy perspective. J. Corp. Citiz. 68, 82-94 (2017)

Wang, C., Naveed, A.: The social inclusion and inequality nexus: EU versus non-EU migrants. International Migration 57(3), 41-62. (2019). https://doi.org/10.1111/imig.12567

World Bank: World Development Report 2002: Building Institutions for Markets. Oxford University Press, Washington (2002)

World Bank.: What Are the Constraints to Inclusive Growth in Zambia? Report No. 44286-ZM, Washington DC: World Bank (2008)

Zhuang, J., Ali, I.: Inclusive growth toward a prosperous Asia: policy implications. ERD Working Paper Series No. 97, Economics and Research Department, Asian Development Bank (2007)

Zhuang, J., de Dios, E.S., Lagman-Martin, A.: Governance and institutional quality and the links with economic growth and income inequality: with special reference to developing Asia. Asian Development Bank (2010)

Zulfiqar, K., Chaudhary, M.A., Aslam, A.: Financial inclusion and its implications for inclusive growth in Pakistan. Pak. Econ. Soc. Rev. 54(2), 297-325 (2016)

Zulfiqar, K., Chaudhary, M.A., Aslam, A.: Convergence hypothesis: a cross country analysis. Pak. Econ. Soc. Rev. 55(1), 201-222 (2017)

Publisher's Note Springer Nature remains neutral with regard to jurisdictional claims in published maps and institutional affiliations. 